\title{
Check-list of chromosome numbers of the family Hygromiidae (Gastropoda: Stylommatophora) with new data on Circassina frutis
}

\author{
Nana Bakhtadze ${ }^{1}$, Nino Chakvetadze ${ }^{1}$, Levan Mumladze ${ }^{1}$, Nino Gabroshvili \\ 1 Institute of Zoology, Ilia State University, 3/5 Kakutsa Cholokashvili Ave., 0162 Tbilisi, Georgia \\ Corresponding author: Nana Bakhtadze (nana.bakhtadze@iliauni.edu.ge)
}

Received 4 June 2021 | Accepted 2 December 2021 | Published 31 December 2021

Citation: Bakhtadze N, Chakvetadze N, Mumladze L, Gabroshvili N (2021) Check-list of chromosome numbers of the family Hygromiidae (Gastropoda: Stylommatophora) with new data on Circassina frutis. Travaux du Muséum National d'Histoire Naturelle “Grigore Antipa” 64(2): 7-20. https://doi.org/10.3897/travaux.64.e69707

\begin{abstract}
Chromosome number data on the Hygromiidae (Gastropoda: Stylommatophora) are summarized and reviewed briefly in the context of the phylogeny of the family. In hygromiids, the haploid chromosome numbers range from 21 to 26 . It is supposed that $\mathrm{n}=21$ is the ancestral chromosome number in the family. The modal haploid number for Hygromiidae is 23. Description of karyotype in terms of chromosome number and morphology of hygromiid land snail Circassina frutis is provided for the first time. The diploid chromosome number of this species is $2 n=46$. The karyotype is symmetric and consists of 21 pairs of metacentric and 2 pairs of submetacentric chromosomes. The karyotype formula is as follows: $2 \mathrm{n}=42 \mathrm{~m}+4 \mathrm{sm}(\mathrm{n}=21 \mathrm{~m}+2 \mathrm{sm})$. The fundamental number $(\mathrm{FN})$ is 92 . Chromosomes range in length from $2.53 \mu \mathrm{m}$ for the smallest pair to $6.00 \mu \mathrm{m}$ for the largest pair. The total length of chromosomes in diploid complement (TCL) is $170.40 \pm 3.22 \mu \mathrm{m}$.
\end{abstract}

\section{Keywords}

Karyotype, phylogeny, Hygromiinae, Leptaxinae, Trochulininae, land snails.

\section{Introduction}

The family Hygromiidae Tryon, 1866 is a highly diverse group of terrestrial pulmonate gastropod mollusks. Representatives of this stylommatophoran family are distributed in the Palaearctic from the Macaronesian Islands in the west to the Russian Far East in 
the east, and reach the northeastern Ethiopian region in the south (Schileyko 2006). The systematics of Hygromiidae, which was mainly based on a few characters of the dart apparatus of the genitalia, has long been controversial, especially the classification of some groups as subfamilies or tribes. It had been revised in the past on several occasions (see references in Barker 1999) and continues to change as modern research methods and new data are made available (Neiber et al. 2017, and references therein).

Cytogenetics has been established as a significant tool providing relevant data to mollusks taxonomy, identification of species, the establishment of phylogenetic and cytogenetic relationships among them, and to the understanding of speciation and evolution mechanisms (Burch 1968a; Patterson 1969; Inaba 1979; Thiriot-Quiévreux 2003). Karyological data such as data of karyotype studies have repeatedly been used to systematic analyses of different level taxa in many stylommatophoran land snails and slugs. The identification of the changes in karyotype composition has proven helpful to clarify the mechanisms of reproductive isolation (and thus speciation) and evolutionary events in this group (see e.g. Perrot 1938; Burch 1965, 1967; Natarajan 1965; Rainer 1967; Kiauta and Butot 1968; Butot and Kiauta 1969; Babrakzai et al. 1975; Reeder 1975; Aparicio 1983; Gill and Cain 1986; Nordsieck 1987; Tatewaki et al. 1987; Panha 1997; Dumrongrojwattana et al. 2005; Vitturi et al. 2005; Awodiran et al. 2012; Kongim and Panha 2013; Patrão et al. 2013; Harbar et al. 2015; Petraccioli et al. 2015; Park 2016, and references in them).

Currently, about 570 species and subspecies are reported for the Hygromiidae (Molluscabase 2021), but only 3.7\% of them are known karyologically. This is at least partly due to the difficulties in obtaining mitotic plates of enough quality to carry out chromosome studies. Moreover, in some cases, a large number of mitotic cells are very rarely found since gonial mitoses happen in a very short time (Burch 1965; Burch 1968b; Boato 1986; Park et al. 1999; Awodiran et al. 2012). Besides, modern cytogenetic techniques have only recently been adopted for studies of Gastropoda (Park 2016). The karyological data sources available for the Hygromiidae include the surveys of Perrot (1937, 1938), Rainer (1967), Butot and Kiauta (1969), Aparicio (1981, 1983), Ramos and Aparicio (1985), Hrabakova et al. (2006), Bakhtadze et al. $(2014,2016)$, and Chakvetadze et al. $(2018,2019)$. However, with rare exceptions (Aparicio 1981, 1983), there are almost no studies with detailed analyses of the karyotypes in the Hygromiidae family.

In the works of Bakhtadze et al. $(2014,2016)$ and Chakvetadze et al. $(2018,2019)$ there are reports on haploid chromosome numbers of some Georgian (Caucasus region) hygromiid species, including Circassina frutis (Pfeiffer, 1859).

C. frutis is a single member of the Caucasian endemic land snail genus Circassina Hesse, 1921 that is widespread in the western and central Caucasus region and the eastern Pontus (Turkey) (Neiber and Hausdorf 2015). The C. frutis is exceptional among hygromiids because it is highly polymorphic in regards to the dart apparatus, i.e. it has either a complete dart apparatus (dart sac plus an accessory sac and mucus glands), only mucus glands, or none of these accessory genital organs. The populations of this species are genetically deeply structured which could be related 
to the existence of multiple Colchic Pleistocene refugia (Neiber and Hausdorf 2015). However, anatomical structuring is hard to explain. Within the Hygromiidae family, accessory organs of the genital system (dart sac and mucus glands) seem to have evolved independently many times (Schileyko 2006; Neiber et al. 2017). However, the case of $C$. frutis, which is represented with all possible combinations of the accessory systems, is rather unique.

The karyological data published so far only refer to the chromosome numbers of $C$. frutis. The haploid (n) and diploid (2n) chromosome numbers for species have been established as 23 and 46, respectively (Bakhtadze et al. 2014; Chakvetadze et al. 2019), and no further details have been reported.

Thus, the aim of this work is to add karyological knowledge on C. frutis and summarize all available karyological data on the Hygromiidae in general.

\section{Material and methods}

The 12 adult specimens of Circassina frutis were collected on the bank of the Maltakva River, the western part of Kolkheti lowland, near port city Poti (Samegrelo-Zemo Svaneti region, Western Georgia; 42.088140 N, 41.705470 E; May 2017) and in Algeti National Park (Kvemo Kartli region, Southeastern Georgia; 41.716945 N, 44.33 E; July 2019). The specimens were identified according to the guidelines of Schileyko (1978) and Schütt (2005). The species nomenclature follows that of Sysoev and Schileyko (2009), Neiber et al. (2017), and MolluscaBase (2021).

Chromosome spreads were obtained from ovotestes, following the squash method as reported previously (Bakhtadze et al. 2014). The gonads of the $0.01 \%$ colchicine solution treated animals were subjected to a hypotonic treatment in a $0.075 \mathrm{M} \mathrm{KCl}$ solution. Then, they were fixed in a $50-60 \%$ acetic acid solution and squashed between the glass slide and cover slip. The prepared slides were stained with the $10 \%$ Romanovskii solution of Azur-eosin ( $\mathrm{pH}$ 6.8). Observations of slides, chromosome counting, and microphotographs were performed with an OMAX Trinocular Compound LED microscope using a 10×100 magnification. Out of 12 specimens, only five animals (41.67\%) appeared karyologically informative; some cell divisions (metaphase stage) could be observed in their gonads. Thirty relatively well-spread metaphase plates $(2 n)$ were analyzed from these five specimens. Five metaphase plates were selected for the morphometric analysis. Based on these five metaphase plates $\mathrm{Ls}$ and $\mathrm{Ll}$ were measured to calculate $\mathrm{TL}(\mathrm{TL}=\mathrm{Ls}+\mathrm{Ll})$, TCL, RL, AR, CI, and SD were estimated, FN (the number of chromosome arms) was determined. All parameters were used to arrange chromosomes in homologous pairs, for karyotyping and constructing of the idiogram. The nomenclature of chromosome morphological types follows that of Levan et al. (1964). The karyotype symmetry/asymmetry index $\left(\mathrm{S} / \mathrm{A}_{\mathrm{I}}\right)$ was calculated according to the formula $\left(\mathrm{S} / \mathrm{A}_{\mathrm{I}}\right)=(1 \times \mathrm{M})+(2 \times \mathrm{SM})+(3 \times \mathrm{A}$ or ST) $+(4 \times \mathrm{T}) / 2 \mathrm{n}$ (Eroğlu 2015) . 
Abbreviations used in the text and tables:

$\mathrm{AR}$ - arm ratio;

CI - centromeric index;

FN - fundamental number;

$\mathrm{Ll}$ - length of the long arm of chromosome;

Ls - length of the short arm of chromosome;

m - metacentric;

$\mathrm{RL}$ - relative length;

SD - standard deviation;

sm - submetacentric;

st - subtelocentric;

TL - chromosome total length;

TCL - total complement length.

\section{Results}

The diploid set (2n) of Circassina frutis consists of 46 chromosomes. Observations on the karyotype and chromosome measurements show that all chromosomes are two-armed and monocentric with a median or submedian position of centromeres (Figs 1-3 and Table 1). Chromosomes range from 2.53 to $6.00 \mu \mathrm{m}$ in length. The first four pairs of chromosomes are larger than the rest. The total length of chromosomes in haploid complement is $85.20 \pm 1.61 \mu \mathrm{m}, \mathrm{TCL}=170.40 \pm 3.22 \mu \mathrm{m}$. Relative lengths of chromosomes vary from 2.97 to $7.04 \mu \mathrm{m}$. The arm ratios and centromeric index indicate that the karyotype consists of 21 pairs of metacentric $(\mathrm{m})$ chromosomes and 2 pairs (2nd and 8 th) of submetacentric $(\mathrm{sm})$ chromosomes. The karyotype formula is as follows: $\mathrm{n}=21 \mathrm{~m}+2 \mathrm{sm}(2 \mathrm{n}=42 \mathrm{~m}+4 \mathrm{sm})$. The fundamental number $\mathrm{FN}=92$. The karyotype symmetry/asymmetry index $S / \mathrm{A}_{\mathrm{I}}=1.09$.

All available karyological information for the family Hygromiidae, with the results of the present study included, are summarized in Table 2. It provides chromosome number data for 21 species and subspecies belonging to 14 genera, 8 tribes, and 3 subfamilies (Hygromiinae Tryon, 1866, Leptaxinae C.R. Boettger, 1909 and Trochulininae Lindholm, 1927) of this family.

\section{Discussion}

The present study provides new karyological information on Hygromiidae species, Circassina fruits, and summarizes all available chromosome number data on the family (Table 2).

In this study, the diploid set of $C$. frutis was confirmed to contain 46 chromosomes, which is in agreement with our previous reports (Bakhtadze et al. 2014; Chakvetadze et al. 2019). Detailed karyotype analysis which was carried out for the first time and 
Table 1. Chromosome morphometric parameters and morphology of Circassina frutis.

\begin{tabular}{|c|c|c|c|c|c|}
\hline Chromosome pair & $\mathrm{TL} \pm \mathrm{SD}(\mu \mathrm{m})$ & AR & CI & RL & Chromosome type \\
\hline 1 & $6.00 \pm 0.00$ & 1.00 & 50.00 & 7.04 & $\mathrm{~m}$ \\
\hline 2 & $5.77 \pm 0.02$ & 1.93 & 34.14 & 6.77 & sm \\
\hline 3 & $5.62 \pm 0.06$ & 1.25 & 44.53 & 6.59 & $\mathrm{~m}$ \\
\hline 4 & $5.50 \pm 0.00$ & 1.17 & 46.06 & 6.45 & $\mathrm{~m}$ \\
\hline 5 & $4.33 \pm 0.11$ & 1.15 & 46.56 & 5.09 & $\mathrm{~m}$ \\
\hline 6 & $4.03 \pm 0.09$ & 1.63 & 38.02 & 4.73 & $\mathrm{~m}$ \\
\hline 7 & $4.02 \pm 0.25$ & 1.43 & 41.51 & 4.71 & $\mathrm{~m}$ \\
\hline 8 & $4.00 \pm 0.14$ & 2.24 & 30.83 & 4.69 & sm \\
\hline 9 & $3.85 \pm 0.24$ & 1.32 & 43.22 & 4.52 & $\mathrm{~m}$ \\
\hline 10 & $3.53 \pm 0.10$ & 1.59 & 38.67 & 4.15 & $\mathrm{~m}$ \\
\hline 11 & $3.50 \pm 0.08$ & 1.44 & 40.95 & 4.11 & $\mathrm{~m}$ \\
\hline 12 & $3.25 \pm 0.11$ & 1.22 & 45.48 & 3.81 & $\mathrm{~m}$ \\
\hline 13 & $3.17 \pm 0.06$ & 1.36 & 42.36 & 3.72 & $\mathrm{~m}$ \\
\hline 14 & $3.10 \pm 0.03$ & 1.36 & 42.42 & 3.64 & $\mathrm{~m}$ \\
\hline 15 & $3.00 \pm 0.00$ & 1.14 & 46.67 & 3.52 & $\mathrm{~m}$ \\
\hline 16 & $3.00 \pm 0.11$ & 1.00 & 50.00 & 3.52 & $\mathrm{~m}$ \\
\hline 17 & $2.95 \pm 0.00$ & 1.36 & 42.37 & 3.46 & $\mathrm{~m}$ \\
\hline 18 & $2.90 \pm 0.00$ & 1.63 & 38.00 & 3.40 & $\mathrm{~m}$ \\
\hline 19 & $2.89 \pm 0.05$ & 1.21 & 45.23 & 3.39 & $\mathrm{~m}$ \\
\hline 20 & $2.88 \pm 0.03$ & 1.24 & 44.71 & 3.38 & $\mathrm{~m}$ \\
\hline 21 & $2.74 \pm 0.01$ & 1.20 & 45.45 & 3.22 & $\mathrm{~m}$ \\
\hline 22 & $2.64 \pm 0.07$ & 1.27 & 44.19 & 3.10 & $\mathrm{~m}$ \\
\hline 23 & $2.53 \pm 0.05$ & 1.28 & 44.10 & 2.97 & $\mathrm{~m}$ \\
\hline
\end{tabular}

the karyotype symmetry/asymmetry index $\left(\mathrm{S} / \mathrm{A}_{\mathrm{I}}=1.09\right)$ show that $C$. frutis has a highly symmetric karyotype. It contains exclusively metacentric and submetacentric chromosomes, with a prevalence of metacentric ones ( $42 \mathrm{~m}$ and $4 \mathrm{sm}$ ). The diploid chromosome number 46 also occurs in other hygromiid species such as Diplobursa pisiformis arpatschaiana (Mousson, 1873), Monacha cantiana (Montagu, 1803), M. cartusiana (O. F. Müller 1774), and Trochulus sericeus (Draparnaud, 1801) (Rainer 1967; Aparicio 1981, 1983). A detailed description of the karyotypes of these species is not available (Table 2). Only for one species, Monacha cartusiana, there is a comparatively detailed description of chromosome morphology (Aparicio 1981, 1983). The karyotype of this species mainly possesses the metacentric/submetacentric chromosomes and only a few subtelocentric chromosomes were observed (Table 2). Aparicio's $(1981,1983)$ data indicate that the karyotype of $M$. cartusiana is also 


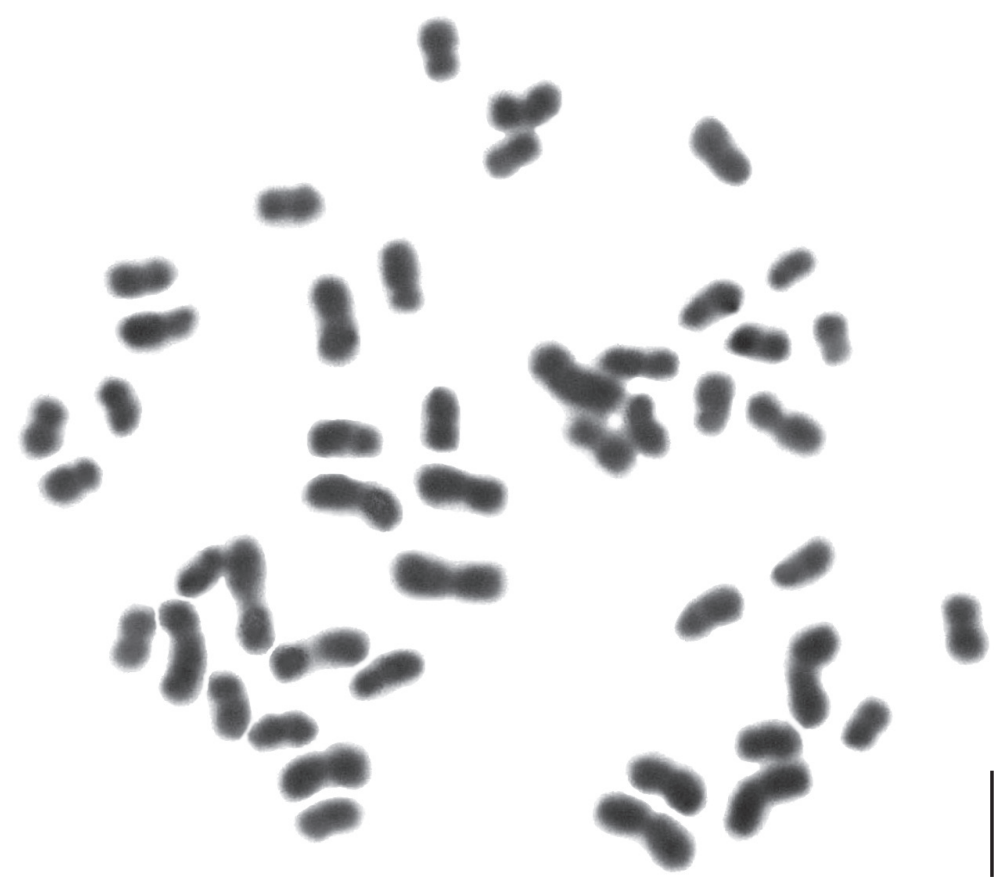

Figure 1. Diploid chromosome set of Circassina frutis $(2 \mathrm{n}=46)$. Scale bar: $6 \mu \mathrm{m}$.

symmetric, although it is less so than the karyotype of $C$. frutis, which includes exclusively the metacentric and submetacentric chromosomes. However, both species have two-armed and mainly metacentric and submetacentric chromosomes. This follows the general trend in gastropod karyotypes (Thiriot-Quiévreux 2003). The high symmetry of karyotypes of $C$. frutis and M. cartusiana can be considered plesiomorphic since the predominance of metacentric chromosomes indicates the relative chromosomal evolutionary stability (White 1978).

Table 2 shows that Hygromiinae tribes possess two different haploid chromosome numbers, 21 and 24 . The number $\mathrm{n}=21$ occurs in the tribe Hygromiini Tryon, 1866, particularly in the genus Hygromia Risso, 1826 that occupies a basal position within the family Hygromiidae (the supraspecific relationships have been adopted from Neiber et al. 2017, figures therein). One can speculate that the haploid chromosome number $\mathrm{n}=21$ is an ancestral character state (plesiomorphy) within hygromiids. The number $\mathrm{n}=24$ is observed in the tribe Perforatellini Neiber, Razkin and Hausdorf 2017, which represents the sister group of Hygromiini, and, along with this tribe, is one of the basal lineages within the family (Neiber et al. 2017). Following this, the Leptaxinae tribes possess one haploid chromosome number $n=26$ (Table 2). Tribe Cryptosaccini Neiber, Razkin and Hausdorf 2017 includes different genera that show the same haploid chromosome number. $\mathrm{n}=26$ seems to be a derived, apomorphic character for this tribe. For tribe Leptaxini C.R. Boettger, 1909 that is represented 


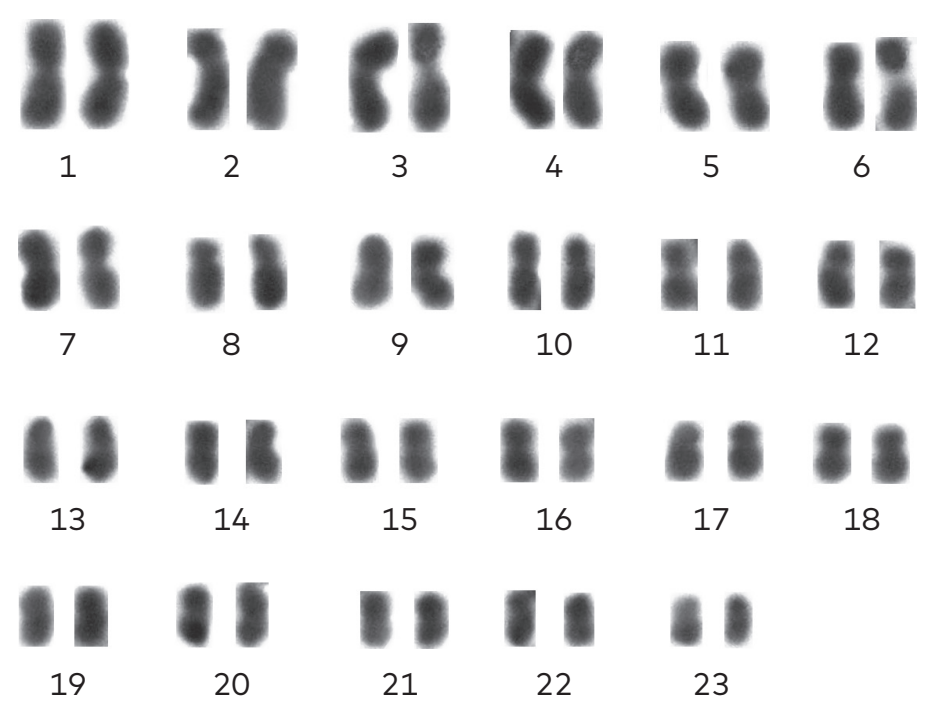

Figure 2. Karyotype of Circassina frutis.

by only one karyologically investigated species, the information is insufficient to obtain any conclusions. The representatives belonging to most genera and tribes of the subfamily Trochulininae, except Euomphalia strigella (Draparnaud, 1801) (tribe Monachaini Wenz, 1930 (1904)), have haploid chromosome number $\mathrm{n}=23$ (Table 2). The haploid chromosome number 23 represents the modal haploid number and seems to be a plesiomorphic character for the subfamily Trochulininae. The other haploid chromosome number $\mathrm{n}=24$, which is also registered in Trochulininae (the genus Euomphalia Westerlund, 1889), is a derived, apomorphic character within this subfamily. However, this same number is also found in Monachoides incarnatus (O. F. Müller, 1774), which is included in another subfamily, Hygromiinae. Since the

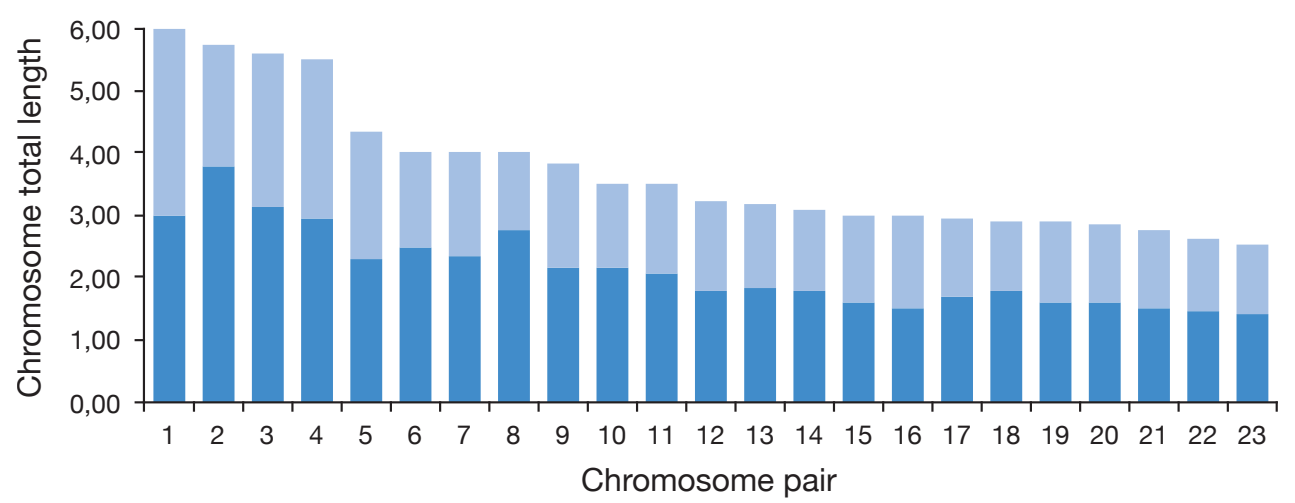

Figure 3. Idiogram of Circassina frutis karyotype. 
Table 2. The karyological reports of land snails in the family Hygromiidae.

\begin{tabular}{|c|c|c|c|c|c|}
\hline \multirow[t]{2}{*}{ Subfamilies } & \multirow[t]{2}{*}{ Tribes and species } & \multicolumn{2}{|c|}{$\begin{array}{l}\text { Chromosome } \\
\text { numbers }\end{array}$} & \multirow{2}{*}{$\begin{array}{l}\text { Karyotype } \\
\text { formula } \\
\text { and FN }\end{array}$} & \multirow[t]{2}{*}{ References } \\
\hline & & $\mathrm{n}$ & $2 n$ & & \\
\hline \multirow[t]{6}{*}{ Hygromiinae } & Hygromiini & & & & \\
\hline & $\begin{array}{l}\text { Hygromia cinctella } \\
\text { (Draparnaud, 1801) }\end{array}$ & 21 & - & - & Perrot 1937,1938 \\
\hline & $\begin{array}{l}\text { Hygromia limbata } \\
\text { (Draparnaud, 1805) }\end{array}$ & 21 & 42 & - & Ramos and Aparicio 1985 \\
\hline & Perforatellini & & & & \\
\hline & $\begin{array}{l}\text { Monachoides incarnatus } \\
\text { (O. F. Müller, 1774) }\end{array}$ & 24 & - & - & $\begin{array}{l}\text { Perrot 1937, } 1938 \text { as } \\
\text { Monacha incarnata Müller }\end{array}$ \\
\hline & & 24 & - & - & $\begin{array}{l}\text { Rainer } 1967 \\
\text { as Perforatella incarnata }\end{array}$ \\
\hline \multirow[t]{5}{*}{ Leptaxinae } & Cryptosaccini & & & & \\
\hline & $\begin{array}{l}\text { Mengoana jeschaui } \\
\text { (Kobelt, 1878) }\end{array}$ & 26 & 52 & - & $\begin{array}{l}\text { Ramos and Aparicio } 1985 \\
\text { as Euomphalia brigantina }\end{array}$ \\
\hline & $\begin{array}{l}\text { Pyrenaearia cantabrica } \\
\text { poncebensis } \\
\text { Ortiz de Zarate Lopez, } 1956\end{array}$ & 26 & 52 & - & $\begin{array}{l}\text { Aparicio } 1981,1983 \text { as } \\
\text { Pyrenaearia poncebensis } \\
\text { Ortiz de Zarate Lopez, } 1956\end{array}$ \\
\hline & Leptaxini & & & & \\
\hline & $\begin{array}{l}\text { Portugala inchoata } \\
\text { (Morelet, 1845) }\end{array}$ & 26 & - & - & Ramos and Aparicio 1985 \\
\hline \multirow[t]{14}{*}{ Trochulininae } & Caucasigenini & & & & \\
\hline & $\begin{array}{l}\text { Caucasigena eichwaldi } \\
\text { (L. Pfeiffer, 1846) }\end{array}$ & 23 & - & - & Chakvetadze et al. 2019 \\
\hline & $\begin{array}{l}\text { Circassina frutis } \\
\text { (L. Pfeiffer, 1859) }\end{array}$ & 23 & - & - & Bakhtadze et al. 2014 \\
\hline & & 23 & 46 & - & Chakvetadze et al. 2019 \\
\hline & & 23 & 46 & $42 m+4 s m ; 92$ & This study \\
\hline & $\begin{array}{l}\text { Fruticocampylaea narzanensis } \\
\text { (Krynicki, 1836) }\end{array}$ & 23 & - & - & Chakvetadze et al. 2018 \\
\hline & Monachaini & & & & \\
\hline & $\begin{array}{l}\text { Diplobursa pisiformis } \\
\text { arpatschaiana } \\
\text { (Mousson, 1873) }\end{array}$ & 23 & 46 & - & $\begin{array}{l}\text { Rainer } 1967 \\
\text { as Euomphalia (Harmozica) } \\
\text { arpatschaiana sewanica } \\
\text { (Martens, 1881) }\end{array}$ \\
\hline & $\begin{array}{l}\text { Euomphalia strigella } \\
\text { (Draparnaud, 1801) }\end{array}$ & 24 & 48 & - & Aparicio 1981 \\
\hline & $\begin{array}{l}\text { Monacha cantiana } \\
\text { (Montagu, 1803) }\end{array}$ & 23 & 46 & - & Rainer 1967 \\
\hline & $\begin{array}{l}\text { Monacha cartusiana } \\
\text { (O. F. Müller, 1774) }\end{array}$ & 23 & - & - & $\begin{array}{l}\text { Perrot } 1937,1938 \text { as Theba } \\
\text { cartusiana Müller }\end{array}$ \\
\hline & & 23 & - & - & $\begin{array}{l}\text { Makino 1951, as Monacha } \\
\text { (Theba) cartusiana) }\end{array}$ \\
\hline & & 23 & - & - & Rainer 1967 \\
\hline & & 23 & 46 & $40 \mathrm{~m} / \mathrm{sm}+6 \mathrm{st}$ & Aparicio 1981, 1983 \\
\hline
\end{tabular}


Table 2. (continued)

\begin{tabular}{|c|c|c|c|c|c|}
\hline \multirow[t]{2}{*}{ Subfamilies } & \multirow[t]{2}{*}{ Tribes and species } & \multicolumn{2}{|c|}{$\begin{array}{l}\text { Chromosome } \\
\text { numbers }\end{array}$} & \multirow{2}{*}{$\begin{array}{l}\text { Karyotype } \\
\text { formula } \\
\text { and FN }\end{array}$} & \multirow[t]{2}{*}{ References } \\
\hline & & $\mathrm{n}$ & $2 n$ & & \\
\hline & \multicolumn{5}{|l|}{ Trochulini } \\
\hline & $\begin{array}{l}\text { Petasina unidentata } \\
\text { (Draparnaud, 1805) }\end{array}$ & 23 & - & - & $\begin{array}{l}\text { Rainer } 1967 \\
\text { as Trichia (Petasina) } \\
\text { unidentata } \\
\text { (Draparnaud, 1805) }\end{array}$ \\
\hline & \multirow[t]{2}{*}{$\begin{array}{l}\text { Trochulus hispidus } \\
\text { (Linnaeus, 1758) }\end{array}$} & 23 & - & - & $\begin{array}{l}\text { Butot and Kiauta } 1969 \\
\text { as Trichia hispida } \\
\text { (Linnaeus, 1758) }\end{array}$ \\
\hline & & 23 & - & - & $\begin{array}{l}\text { Hrabakova } \\
\text { et al. } 2006\end{array}$ \\
\hline & $\begin{array}{l}\text { Trochulus montanus } \\
\text { (S. Studer, 1820) }\end{array}$ & 23 & - & - & $\begin{array}{l}\text { Butot and Kiauta } 1969 \\
\text { as Trichia striolata } \\
\text { montana (Studer, 1820) }\end{array}$ \\
\hline & $\begin{array}{l}\text { Trochulus plebeius } \\
\text { (Draparnaud, 1805) }\end{array}$ & 23 & - & - & Hrabakova et al. 2006 \\
\hline & $\begin{array}{l}\text { Trochulus sericeus } \\
\text { (Draparnaud, 1801) }\end{array}$ & 23 & 46 & - & $\begin{array}{l}\text { Rainer } 1967 \\
\text { as Trichia (Trichia) sericea } \\
\text { (Draparnaud, 1801) }\end{array}$ \\
\hline & $\begin{array}{l}\text { Trochulus striolatus } \\
\text { danubialis } \\
\text { (Clessin, 1874) }\end{array}$ & 23 & - & - & $\begin{array}{l}\text { Butot and Kiauta } 1969 \\
\text { as Trichia striolata } \\
\text { danubialis (Clessin, 1874) }\end{array}$ \\
\hline & $\begin{array}{l}\text { Trochulus villosus } \\
\text { (Draparnaud, 1805) }\end{array}$ & 23 & - & - & $\begin{array}{l}\text { Rainer } 1967 \\
\text { as Trichia villosa } \\
\text { (Studer, 1789) }\end{array}$ \\
\hline & \multicolumn{5}{|l|}{ Urticicolini } \\
\hline & $\begin{array}{l}\text { Urticicola umbrosus } \\
\text { (C. Pfeiffer, 1828) }\end{array}$ & 23 & - & - & $\begin{array}{l}\text { Butot and Kiauta } 1969 \\
\text { as Zenobiella umbrosa } \\
\text { (C. Pfeiffer, 1828) }\end{array}$ \\
\hline
\end{tabular}

haploid chromosome number $2 \mathrm{n}=24$ occurs in the separate lineages of hygromiid land snails (the subfamilies Hygromiinae and Trochulininae, see Neiber et al. 2017), it can be considered as a case of homoplasy within the family Hygromiidae.

Table 2 indicates that in the family Hygromiidae the haploid chromosome numbers range from 21 to 26 . This range is different from those reported by Barker in $1999(21-27)$ and $2001(26-30)$, respectively. Furthermore, haploid chromosome numbers $21,23,24$, and 26 seem to be characteristic for the Hygromiidae in general. $n$ $=21$ is the lowest chromosome number in the family. The most common chromosome number within hygromiids is $\mathrm{n}=23$. Since it occurs in the majority of investigated species (66.67\%), genera, and tribes, it represents the modal haploid number for the family. $\mathrm{n}=26$ is the highest haploid chromosome number in the Hygromiidae so far. By Burch (1965), Patterson (1969), and Nakamura (1986), many molluscan groups are generally conservative concerning chromosome change, and the difference between the haploid numbers of the species in a particular family is rarely more than 
one or two chromosomes. Since four different haploid chromosome numbers (21, 23, 24, and 26) occur in the Hygromiidae, this group is not conservative in regards of the haploid chromosome number at the family level. However, the stability of the chromosome number shows at the tribe level. Almost all tribes have the same haploid chromosome number, with the exception of Monachaini which presents two haploid chromosome numbers, 23 and 24 (Table 2). For three tribes, Leptaxini, Perforatellini, and Urticicolini Neiber, Razkin and Hausdorf 2017, the karyological information is highly scarce and insufficient to obtain any conclusions about the constancy or variety of their chromosome numbers (Table 2). The diploid chromosome number and other karyotype details are currently available only for several hygromiids. Particularly, nine species, including C. frutis analyzed here, have the diploid chromosome numbers 42 , 46, 48, and 52. Chromosome morphology is described only for two species, C. frutis, and $M$. cartusiana (see above).

Although the karyological data for the Hygromiidae family is still highly insufficient, it seems that in the evolution of the family, there is a tendency of increasing of the chromosome number (from $n=21$ in more basal taxa to $n=26$ in the more recent ones). The karyotype diversity of this land snails group seems to support the hypothesis of Patterson and Burch (1978) that molluscan chromosome numbers tend to increase with evolution, and the more primitive taxa have lower chromosome numbers. The increase of the chromosome number might play a role in the evolution of the Hygromiidae. Within hygromiid taxa, Neiber et al. (2017) indicate high levels of homoplasy in the development of the genital system. However, due to very limited karyological data, it is not yet possible to correlate anatomical and chromosomal changes in hygromiid snails. Nonetheless, the family Hygromiidae seems to be a good model group to study chromosomal and morpho-anatomical evolution in the context of phylogenetic relationships.

\section{Acknowledgements}

We are very grateful to Dr. Valentina G. Kuznetsova (Department of karyosystematics, Zoological Institute, Russian Academy of Sciences, St. Petersburg) for valuable comments on the manuscript and linguistic corrections. We are thankful Dr. Edisher Tskhadaia (Institute of Zoology, Ilia State University, Tbilisi) for help in fieldwork. We also want to thank Veriko Bakhtadze (Archil Eliashvili Institute of Management Systems of Georgian Technical University, Tbilisi) for technical assistance.

\section{References}

Aparicio MT (1981) Cytotaxonomic studies of the family Helicidae (Gastropoda, Pulmonata). Genética Ibérica 33: 211-224. 
Aparicio MT (1983) Estudio morfológico y citotaxonómico de algunos Helicidos de la fauna española, en especial de la región central. Doctoral thesis, Faculty of Biological Sciences, Complutense University of Madrid, Madrid, 299 pp. [in Spanish]

Awodıran MO, Awopetu JI, Akıntoye MA (2012) Cytogenetic study of four species of land snails of the family Achatinidae in South-Western Nigeria. Ife Journal of Science 14(2): 233-235.

Babrakzai N, Miller WB, Ward OG (1975) Cytotaxonomy of some Arizona Oreohelicidae (Gastropoda: Pulmonata). Bulletin of the American Malacological Union for 1974, Inc 41: 4-11.

Bakhtadze NG, Chakvetadze NL, Mumladze LJ, Bakhtadze GI, Tskhadaia EA (2014) Karyological studies in terrestrial mollusks (Mollusca: Gastropoda: Pulmonata) of Georgia. International Scientific Conference «Biological diversity and conservation problems of the fauna of the Caucasus-2», Yerevan, Armenia. Proceedings of the Conference, pp. 59-63. https://doi.org/10.13140/2.1.4677.1525

Bakhtadze NG, Chakvetadze NL, Mumladze LJ, Bakhtadze GI, Tskhadaia EA (2016) Karyological Data of Terrestrial Mollusks (Mollusca: Gastropoda: Pulmonata) of Georgia. Proceedings of the Institute of Zoology 25: 23-27.

Barker GM (1999) Naturalised terrestrial Stylommatophora (Mollusca: Gastropoda). Fauna of New Zealand 38: 253 pp.

Barker GM (2001) Gastropods on Land: Phylogeny, Diversity and Adaptive Morphology. In: Barker GM (Ed.) The biology of terrestrial molluscs. CABI Publishing, New York, 1-146. https://doi.org/10.1079/9780851993188.0001

Boato A (1986) A preliminary karyological analysis of five species of Solatopupa (Pulmonata, Chondrinidae). Bolletino di zoologia 53: 15-22. https://doi.org/10. $1080 / 11250008609355476$

Burch JB (1965) Chromosome number and systematics in euthyneuran snails. First European Malacological Congress, 1962, London, England, United Kingdom. Proceedings of the Congress, p. 215-241.

Burch JB (1967) Cytological Relationships of some Pacific Gastropods. Venus 25(3-4): 118-135. https://doi.org/10.18941/venusjjm.25.3-4_118

Burch JB (1968a) Cytotaxonomy of some Japanese Semisulcospira (Streptoneura: Pleuroceridea). Journal of Conchology 107: 3-52.

Burch JB (1968b) A Tissue Culture Technique for Caryotype Analyses of Pulmonate Land Snails. Venus 27(1): 20-27.

Butot LJM, Kiauta B (1969) Cytotaxonomic observations in the stylommatophoran family Helicidae, with considerations on the affinities within the family. Malacologia 9(1): 261-262.

Chakvetadze N, Bakhtadze N, Mumladze L, Bakhtadze G, Tskhadaia E, Gabroshvili N (2018) Contribution to Karyological Data of Terrestrial Mollusks (Mollusca: Gastropoda) of Georgia. Bulletin of the Georgian National Academy of Sciences 12(4): 108-112.

Chakvetadze N, Bakhtadze N, Mumladze L, Tskhadaia E (2019) Chromosome numbers of terrestrial mollusks (Mollusca: Gastropoda) of Georgia. Arianta 7: 10-11. 
Dumrongrojwattana P, Matchacheep S, Yenjai N (2005) Karyotype of Thai Crown Snails Macrochlamys asamurai Panha, 1996 and Syama diadema (Dall, 1897) (Pulmonata: Ariophantidae). Kasetsart Journal - Natural Science 39: 236 - 241.

Eroğlu HE (2015) Which chromosomes are subtelocentric or acrocentric? A new karyotype symmetry/asymmetry index. Caryologia: International Journal of Cytology, Cytosystematics and Cytogenetics 68(3): 239-245. http://dx.doi.org/10.1080/00087114. 2015.1032614

Gill JJB, Cain AJ (1986) The chromosomes of Cepaea vindobonensis (Pulmonata: Helicidae) and the relationship between this species and the rest of the genus. Biological Journal of the Linnean Society: 28(3): 315-320. https://doi.org/10.1111/j.1095-8312.1986.tb01760.x

Harbar AV, Kadlubovska NS, Harbar DA (2015) Comparative Karyotype Analysis of Slugs of the Genus Arion (Gastropoda, Pulmonata, Arionidae). Vestnik zoologii 49(4): 299-304. https://doi.org/10.1515/vzoo-2015-0031 [in English, with Russian summary]

Hrabakova M, Jurickova L, Petrusek A (2006) Taxonomy of the genus Trochulus (Gastropoda: Hygromiidae) in the Czech Republic. Molluscan forum-2006, London, United Kingdom. Programme and Abstracts of forum, p. 12.

Inaba A (1979) Chromosomes and phylogeny of Mollusca. The Japanese Society of Systematic Zoology, Circular 52: 1-7.

Kiauta B, Butot LJM (1968) The chromosomes of Succinea (Succinella) oblonga Draparnaud, 1801, with considerations on the status of the subgenus Succinella Mabille, 1870 (Gastropoda, Euthyneura: Succineoidea). Beaufortia: Series of miscellaneous publications 16(210): 1-11.

Kongim B, Panha S (2013) Karyotypic analysis of the terrestrial snail genus Phuphania (Pulmonata: Dyakiidae) with description of a new species from Thailand. Journal of Conchology 41(3): 319-325.

Levan A, Fredga K, Sandberg AA (1964) Nomenclature for Centromeric Position on Chromosomes. Hereditas 52(2): 201-220. https://doi.org/10.1111/j.1601-5223.1964. tb01953.x

Makino S (1951) An Atlas of the Chromosome Numbers in Animals, $2^{\text {nd }}$ ed. ( $1^{\text {st }}$ American Ed.). The Iowa State College Press, Ames, Iowa, xxviii + 290 pp. https://doi.org/10.5962/ bhl.title.7295

MolluscaBase (2021) (www.molluscabase.org) [Accessed on 17.10.2021]

Nakamura HK (1986) Chromosomes of Archaeogastropoda (Mollusca Prosobranchia) with some remarks on their cytotaxonomy and phylogeny. Publications of the Seto Marine Biological Laboratory 31: 191-268. https://doi.org/10.5134/176126

Natarajan R (1965) Cytological studies in Stylommatophora. The American Malacological Union, Inc 32: 15-16.

Neiber MT, Hausdorf B (2015) Phylogeography of the land snail genus Circassina (Gastropoda: Hygromiidae) implies multiple Pleistocene refugia in the western Caucasus region. Molecular Phylogenetics and Evolution 93: 129-142. https://doi.org/10.1016/j. ympev.2015.07.012 
Neiber MT, Razkin O, Hausdorf B (2017) Molecular phylogeny and biogeography of the land snail family Hygromiidae (Gastropoda: Helicoidea). Molecular Phylogenetics and Evolution 111: 169-184. https://doi.org/10.1016/j.ympev.2017.04.002

Nordsieck H (1987) Revision des Systems der Helicoidea (Gastropoda: Stylommatophora). Archiv für Molluskenkunde 118(1-3): 9-50. [in German]

Panha S (1997) Taxonomy and karyotypes of land pulmonate snails of Thailand. Research report (Project: RSA/15/1994). Department of Biology, Faculty of Science, Chulalongkorn University, Bangkok, 72 pp.

Park GM (2016) Karyological analysis of Korean endemic land snail, Koreanohadra kurodana (Gastropoda: Bradybaenidae). Caryologia: International Journal of Cytology, Cytoststematics and Cytogenetics 69(4): 339-342. http://dx.doi.org/10.1080/00087114. 2016.1224403.

Park GM, Kim JJ, Chung PR, Wang Y, Min DY (1999) Karyotypes on three Species of Chinese mesogastropod snails, Semisulcospira libertine, S. dolichostoma and Viviparus rivularis. The Korean Journal of Parasitology 37(1): 5-11. https://doi.org/10.3347/kjp.1999.37.1.5

Patrão C, De Sousa J, Jordaens TK, Backeljau T, Castilho R, Leitão A (2013) Geomalacus and Letourneuxia (Mollusca, Pulmonata): A Cytogenetic Assessment. Malacologia 56(1-2): 333-338. https://doi.org/10.4002/040.056.0222

Patterson CM (1969) Chromosomes of molluscs. $2^{\text {nd }}$ Symposium of Mollusca, 1968, Cochin, India. Proceedings of the Symposium, Marine Biological Association of India symposium series 3, Part 2, pp. 635-686.

Patterson CM, Burch JB (1978) Chromosomes of pulmonate molluscs. In: Fretter V, Peake J (Eds) Pulmonates, Vol 2A, Systematics, evolution and ecology. Academic Press, New York, London, San Francisco: 171-217.

Perrot M (1937) Recherches sur les chromosomes de Pulmonés stylommatophores (note préliminaire). Compte rendu des séances de la Société de physique et d'histoire naturelle de Genève 54(1): 119-121. [in French]

Perrot M (1938) Etude de cytologie comparée chez les gastéropodes pulmones. Revue suisse de zoologie 45(20): 487-566. [in French]

Petraccioli A, Capriglione T, Colomba M, Crovato P, Odierna G, Sparacio I, Maio N (2015) Comparative cytogenetic study in four alopiinae door snails (Gastropoda, Clausiliidae). Malacologia 58(1-2): 225-232. https://doi.org/10.4002/040.058.0207

Rainer M (1967) Chromosomenuntersuchungen an Gastropoden (Stylommatophora). Malacologia 5(3): 341-373. [in German with English, Spanish and Russian summaries] Ramos MA, Aparicio MT (1985) A cytotaxonomic study of some Spanish and Portuguese Helicidae (Pulmonata, Geophila). Malacological review 18(1-2): 73-82.

Reeder RL (1975) Comparative Karyotype Analyses of Selected Members of the Genus Ashmunella (Mollusca: Pulmonata: Polygyridae). PhD Dissertation, The University of Arizona, ix $+57 \mathrm{pp}$.

Schileyko AA (1978) Nazemnye mollyuski nadsemeystva Helicoidea. Fauna SSSR, Mollyuski (Nauka, Leningrad) 3(6): 1-384. [in Russian]

Schileyko AA (2006) Treatise on recent terrestrial pulmonate molluscs, Part 14. Helicodontidae, Ciliellidae, Hygromiidae. Ruthenica, Supplement 2: 1907-2047. 
Schütt H (2005) Turkish land snails $1758-2005,4^{\text {th }}$ revised and enlarged edition. Verlag Natur \& Wissenschaft, Solingen, $559 \mathrm{pp}$.

Sysoev AV, Schileyko AA (2009) Land snails and slugs of Russia and adjacent countries. Pensoft Series Faunistica, Vol. 87, Pensoft Publishers, Sofia, Moscow, 312 pp.

Tatewaki R, Kitada J, Masuda O (1987) Karyotypes of Two Species of Genus Euhadra, Euhadra callizona and Euhadra peliomphala simodae (Bradybaenidae, Gastropoda). Proceedings of the Japan Academy (Ser. B) 63(8): 293-296. https://doi.org/10.2183/pjab.63.293

Thiriot-Quiévreux C (2003) Advances in chromosomal studies of gastropod molluscs. Journal of Molluscan Studies 69: 187-202. https://doi.org/10.1093/mollus/69.3.187

Vitturi R, Libertini A, Sineo L, Sparacio I, Lannino A, Gregorini A, Colomba M (2005) Cytogenetics of the land snails Cantareus aspersus and C. mazzullii (Mollusca: Gastropoda: Pulmonata). Micron 36: 351-357. https://doi.org/10.1016/j.micron.2004.12.010

White MJD (1978) Modes of speciation. W. H. Freeman \& Company, San Francisco, California, USA, viii+456 pp. 